\title{
Critical Thinking in the Schools: Why Doesn't Much Happen?
}

\section{A review of the literature}

\section{IAN Wright University of British Columbia}

\begin{abstract}
The teaching of critical thinking in public schooling is a central aim. Yet, despite its widespread acceptance in curriculum documents, critical thinking is rarely taught. Motivated by Onosko (1991), and by the efforts of some post-secondary instructors of critical thinking to get critical thinking taught in schools, I look at the recent literature on (a) critical thinking in the social studies, (b) definitions of, and programs in critical thinking, (c) teachers beliefs, and (d) the milieus in which teachers work. I pose three questions and provide tentative hypotheses as to why critical thinking is not being implemented in schools.
\end{abstract}

Résumé: L'enseignement de la pensée critique dans les écoles publiques est un but très important. Mais malgré son acceptation générale dans les programmes d'études, on l'enseigne rarement. Je m'inspire des travaux de Onosko (1991) et des efforts de certains enseignant(e)s de la pensée critique au niveau postsecondaire pour puiser dans les publications sur (a) la pensée critique dans les sciences sociales, (b) des définitions de la pensée critique et les programmes visant à former la pensée critique, (c) les croyances des enseignant(e)s, (d) les milieus dans lesquels les enseignant(e)s travaillent. Je soulève trois questions et propose des hypothèses provisoires pour

Keywords: critical thinking, implementation, teachers, schools, teacher abilities, teacher beliefs, teacher dispositions, schoolchildren

\section{Introduction}

Some instructors who teach informal logic and critical thinking at the post secondary level also present workshops and write curriculum materials to help public school teachers develop critical thinking programs. Two prominent examples are Richard Paul, who has made it his mission to get critical thinking incorporated into the school curriculum, and Matthew Lipman and his colleagues with their Philosophy for Children program. Yet, despite some small pockets of success, little in the way of critical thinking instruction occurs in schools. Why is this so? Is there any hope that kindergarten through graded $12(\mathrm{~K}-12)$ students will be taught how to think critically so that when they take post-secondary courses they will have some prerequisite background knowledge, skills and dispositions? Can we learn anything from school experiences to help us in our efforts to have critical thinking taught in post-secondary courses? 


\section{Ian Wright}

Discussion about critical thinking in the public schools is very different from that at the university level. Public schools and institutions of higher education are very different places. Universities and colleges are (supposedly) autonomous institutions and are (supposedly) hotbeds of critical inquiry. Schools are neither. Whereas critical thinking and informal logic courses are recognized as legitimate subjects at the university and college levels, there is little if any recognition at the school level. No schools that I know of teach courses in critical thinking.' Rather, critical thinking is meant to be infused into all courses and all teachers are expected to teach it. Yet, at the post secondary level, only those acknowledged as experts are supposed to teach critical thinking. However, as with public school teachers, there are moves to persuade all post-secondary teachers to teach critical thinking through their own disciplines. Post-secondary teachers of critical thinking/informal logic usually have a home in a department of philosophy and can join professional organizations such as the Association for Informal Logic and Critical Thinking. Public school critical thinking teachers have no department home and there are only two national critical thinking associations: Matthew Lipman's International Council for Philosophical Inquiry with Children, and Richard Paul's National Council for Excellence in Critical Thinking. Neither of these yet has the same stature as does, for example, the National Council for the Social Studies. Whereas most university curricula are under the purview of the university, school curricula are created by departments of education that are influenced by public opinion. Witness the recent uproar over the history standards for schools, the teaching of creationism (now called "intelligent design" according to the debate in Ohio), and the banning of controversial books in several States. The public opinion factor is one reason why critical thinking is rarely taught in public schools. But there are other reasons that mitigate against the teaching of critical thinking. Those of us who wish to help teachers implement critical thinking in their classrooms or who are working to persuade their colleagues to embrace critical thinking in post-secondary courses should be aware of those influences pertinent to the post-secondary context. Here, I will concentrate on one school subject area-social studies-because I know it best. I would argue, however, that the hypotheses I advance in relation to social studies and social studies teachers will apply to other subject areas as well.

\section{Critical thinking and the social studies}

For over half a century, one of the major aims of education has been the development of critical thinking. In social studies it has been recognized since 1916 that critical thinking is central to citizenship education (Barr, Barth \& Shermis, 1977). Yet, according to Case and Wright (1997), rhetoric outstrips practice. Witness the 1942 Yearbook for the National Council for the Social Studies in which it was observed that American social studies teachers had, "accepted critical thinking in principle without bothering to define the term precisely or to do much by way of direct instruction to see this goal was achieved" (Anderson, cited in Parker, 
1991 , p. 345). Nearly fifty years later, Fraenkel stated that critical thinking was a goal and not a classroom reality (Fraenkel, 1991, p. 323).

During the 1980s, the need for critical thinking was emphasized in the USA by the Commission on the Humanities (1980), the College Board (1983), the Task Force on Education for Growth of the Education Commission of the States (1983), and Boyer's Carnegie Foundation report (1983). Journals devoted whole issues to critical thinking, conferences were held, and workshops for teachers proliferated. The California State University system mandated the teaching of critical thinking as a graduation requirement. Yet in the 1990s, attendance at the International Conference on Critical Thinking at Sonoma State University declined from over a thousand in the halcyon days of the 1980s, to less than 300 . The number of "hits" in the use of "critical thinking" as a descriptor on the ERIC system declined by over $80 \%$ between 1992 and 1998 (author's count).

Onosko (1991) found in his study of fifty-six social studies teachers that there were a number of interrelated factors influencing the lack of teaching of critical thinking. These barriers were: (1) teaching was viewed as knowledge transmission, not critical thinking; (2) information was taught in a broad and superficial way, thus not allowing the kind of in-depth study required for critical thinking; (3) teachers had low expectations of students and did not think they were capable of critical thought; and (4) large class size and lack of preparation time mitigated against the teaching of critical thinking.

In this article, I extend Onosko's conclusions by focussing on three other related factors: the difficult choices teachers have to make between competing definitions of critical thinking; the question of teachers' epistemologies and their abilities to teach critical thinking; and the milieus in which teachers work and the impact these have on the implementation of critical thinking.

\section{Conceptions of critical thinking}

Question: What effects, if any, do the competing definitions and programs in critical thinking have on the implementation of critical thinking in the social studies classroom?

\section{Introduction}

How teachers define critical thinking will determine what they teach and, often, how they will teach it. Teachers know that they should be helping students to think critically, but their notions of this are often colored by educational literature that is not informed by a deep understanding of critical thinking. They are confronted with a variety of curriculum materials and programs devoted to the teaching of "thinking" (higher-order thinking, reflective thinking, problem-solving, issue-centered instruction, decision-making, inquiry, and so on) and do not know how to choose among them. They have not usually been exposed to the definitional 
conversation, and the scant evidence that exists would point to the fact that teachers and curriculum developers have quite different conceptions of critical thinking from those advanced by, among others, Ennis (1991), Paul (1992), Hatcher (2000), Siegel (1990), McPeck (1998), Lipman (1988), and Bailin and her co-authors (1999b).

\section{The skills conception of critical thinking}

The skills conception of critical thinking seems to be the most prevalent in educational circles. For example, Ford (1988) found that the developers of the 1983 British Columbia social studies curriculum defined critical thinking as the skills contained in the higher levels of Bloom's Taxonomy: analysis, synthesis and evaluation. Critical thinking objectives are usually positioned in the skills sections of curriculum guides rather than in the cognitive or affective. This is not surpris- . ing, for the authors of the Curriculum Standards for Social Studies (National Council for the Social Studies, 1994) place the criteria central to critical thinking in the essential skills appendix (p. 149). Here are listed such skills as "Compare and contrast credibility of differing accounts of the same event," "Test the validity of the information, using criteria such as source, objectivity, technical correctness, currency," and "Draw inferences from factual material." Whereas we may all agree that these are some of the "skills" needed to be a critical thinker, even these are not always recognized or understood. This is evidenced in Paul, Elder and Bartell's (1997) study for the California Commission of Teacher Credentialing. They interviewed 101 Education Faculty and 39 members of Faculties of Arts and Sciences in California. Although $89 \%$ stated that critical thinking was of prime importance in their instruction, only $8 \%$ could provide a clear conception of the critical thinking skills they thought were important for students to develop. And of these skills, only $8 \%$ of those interviewed could differentiate an assumption from an inference, and only $4 \%$ could state the difference between an inference and an implication. Little wonder that their would-be-teacher students would have an inadequate understanding of what is entailed in thinking critically.

\section{Problems with the skills conception of critical thinking}

Most critical thinking activities in textbooks are of the skills type where there are correct answers (Risby, 1987), or the questions posed ask students to give their opinion on an issue, but no criteria are provided to adjudicate between mere opinion and sound opinion. Beyer $(1989,1991)$, in his series of books on teaching thinking skills, does not include specifics on whether someone has predicted well, or summarized reliably (the critical part of thinking), and the problem-solving lessons all involve logical puzzles where there are right answers. I would hypothesize that most teachers teach skills and that they would say they are teaching critical thinking. However, this may not be the case at all. They are teaching skills but not in a critical thinking manner. That is, they may ask students to infer and 
generalize, without teaching them what would qualify as a plausible inference or a sound generalization.

Despite the criticisms of viewing critical thinking as a skill or set of skills, (Degenhart, 1988; Hart, 1993; Bailin, Case, Coombs and Daniels, 1999a), it appears that teachers treat critical thinking as a set of skills and procedures. This is understandable given that they are unlikely to have been exposed to critical thinking or to the criticisms of viewing critical thinking as a set of skills in their undergraduate or professional education (Su, 1990). Skills are quite easy to grasp. Talk of critical thinking criteria is disquieting, as it requires teachers to make judgments about truth, reliability, and acceptability.

\section{Programs in critical thinking}

There have been many attempts to define critical thinking. Readers here will be familiar with the work of Richard Paul, John McPeck, Robert Ennis, Matthew Lipman. Harvey Siegel, Donald Hatcher, and Sharon Bailin, Roland Case, Jerrold Coombs and LeRoi Daniels, among others. However only three of these scholars-Richard Paul, Matthew Lipman, and Sharon Bailin and her co-authors-have developed curricula materials for use in schools. These differ. Paul has produced curriculum materials for infusing critical thinking into all subject areas; Lipman has a thorough and voluminous program (The Philosophy for Children program) that requires well-trained teachers and a separate timetable slot. Applying the Bailin, Case, Coombs and Daniels's (1999b) conception of critical thinking, Daniels and Case (1997) have produced "critical challenges" that can be incorporated into many subject areas in all grade levels.

Even though there are some similarities between the approaches to teaching critical thinking advanced by Paul, Lipman, and Bailin, et al.-they all stress the significance of standards of reasoning - their implementation into curriculum and instruction has resulted in different approaches (Wright, 1993a). Teachers have to decide which approach to take, but do not always have the necessary expertise to decide.

Recently, Hatcher (2000) has argued for a new definition of critical thinking because unless there is some common agreement about its meaning there will be problems in deciding what to teach in the name of critical thinking, how to assess it, and how to persuade others that it ought to be an educational goal. Hatcher is correct in that it would be much easier for teachers to implement critical thinking if there was an agreed-upon definition. However, even if there was an agreed-upon definition, how it is translated into practice will depend upon the assumptions teachers hold about education, teaching, and students. As we will see, these are powerful influences.

Given the varying definitions of critical thinking and the variety of ways that critical thinking can be incorporated into the school curriculum, it is no wonder 


\section{Ian Wright}

that teachers do not know where to turn. Teachers can only make reasonable decisions about instruction in critical thinking if they are knowledgeable about it. Thus, anyone interested in introducing critical thinking into the schools should determine how teachers conceive of critical thinking and develop their understanding of it.

My hypothesis is that the varying conceptions of, and programs in, critical thinking make it difficult for teachers to make decisions, and this is one reason why there is a lack of critical thinking in social studies and other classrooms. Further, the prevailing skills view is problematic.

Given this school based analysis, is the hypothesis tenable at the post-secondary level? Do post-secondary instructors also have problems with definitions and do these influence their non-adoption of critical thinking? For example, Bell (2001) points out that definitions of critical thinking differ in psychology textbooks. Tsui (2001), an educational researcher who studied faculty attitudes towards critical thinking, defined critical thinking as a group of skills. She omits any mention of the dispositions required and her definition raises all the questions mentioned above concerning the skills conception of critical thinking. Further, Johnson and Blair (1994, pp. 5-6) point out that there are even disputes about the place of logic in critical thinking and the place of informal logic in both. Thus, at both the school and post-secondary levels, questions arise as to how critical thinking is to be conceived. And, if critical thinking is viewed as applied epistemology, then there may be even more reason for post-secondary instructors to leave critical thinking to the philosophy department!

\section{The critical thinking abilities of teachers}

Question: Do teachers have the necessary abilities and dispositions to teach critical thinking?

\section{Introduction}

It is a truism that if teachers are to teach critical thinking they must have the necessary knowledge, abilities and dispositions. In Section 1, I hypothesized that most teachers do not have the background knowledge necessary for appropriately conceptualizing critical thinking. Here, I present the available evidence on teacher abilities.

\section{Teacher abilities}

Even though there are differing conceptions of critical thinking, there is clear agreement that the sorts of competencies outlined by Ennis (1991), for example, are crucial to critical thinking. However, we know very little about the competencies of teachers. Research evidence is scant and existing studies in social studies are small in scale. For example, Unks (1985) had a sample of 293 social studies 
teachers in 43 high school systems in the USA. He found that only $51.8 \%$ of them could clearly distinguish between statements of fact and statement of opinion (a distinction regarded as a critical thinking skill).

In a study by Richard Paul (1992), 81 teachers enrolled in a critical thinking workshop assessed two essays on the topic of rock music, one being well reasoned the other poorly reasoned. They gave the poorly-reasoned essay an average score of 5.4 (out of 8 ) and the well reasoned one an average score of 3.9. Fortynine of the teachers gave the poorly-reasoned essay a score of 6,7 , or 8 , while only 18 teachers gave the well-reasoned essay a 6,7 , or 8 . According to Paul, teacher justifications for their scores "reveals a great deal of misunderstanding of the nature of reasoning" (p. 5).

Kuhn (1991) interviewed 5 teachers in her study of the reasoning of 160 people between the ages of 14 and 60 in the USA. She found that that these teachers' reasoning about why students failed at school showed no more expertise than did other subjects' and was inferior in some aspects. They could give no genuine evidence to support their theories. Wright (1993b) used Coomb's (1990) test of practical reasoning and determined that $50 \%$ (of a sample of 450 ) of pre-service teachers at a western Canadian university could not differentiate between empirical, conceptual and value claims. However, they were able to differentiate between the moral and prudential points of view and between a concept and a conceptiondistinctions necessary in critical thinking.

Critical thinking abilities could be enhanced if teachers were exposed to them in their training. However, it appears that this is not the case. Su (1990), reporting on data drawn from Goodlad's (1990) study of the education of educators, interviewed 45 teacher candidates, 40 teacher educators, and 16 co-operating teachers in eleven institutions. These ranged from flagship public universities to private liberal arts colleges. He found that many teacher educators had a functional view of education, viewing basic skills training as being one of the major goals. Even though this group stated that they valued critical thinking, they did not implement it in their classrooms. This is borne out in Paul, Elder and Bartell's (1997) study mentioned above. They found that the vast majority of teacher educators could not list any critical thinking skills and that $41 \%$ said that knowledge, truth and sound judgement were a matter of personal preference or subjective taste.

While limited evidence suggests that critical thinking abilities are not well developed, Paul's finding that teachers viewed truth as a matter of personal taste is disturbing. It leads to the question as to whether teachers have the necessary dispositions to teach critical thinking.

\section{The dispositions and beliefs of teachers}

If we assume that,

man [sic] is not a rational calculator but is a reluctant decision maker-beset by conflict, doubts, and worry, struggling with incongruous longings, an- 
tipathies, and loyalties, and seeking relief by procrastination, rationalizing or

denying responsibility for his own choices (Janis and Mann, 1977, p. 15),

then we can also assume that teachers make the same sorts of mistakes as do managers, executives, students, and others studied by researchers interested in how people make decisions. These mistakes include not considering more than two alternatives, not carefully weighing the pros and cons of taking any particular action, not considering information that does not support initial solutions, using only one rule to make a decision even if it is inappropriate in a particular decision context, and obeying an authority even when that is inappropriate. Being a critical thinker is no easy task, for, as Newmann $(1991$, p. 391) attests,

[e]ven in the most supportive setting, humans have great difficult in subjecting their beliefs to continuous scrutiny, exercising independent judgment, seriously considering ideas that may challenge conventional wisdom, [and] resolving ambiguity and contradiction....

At a fundamental level, it is clear that teachers not only require a defensible definition of critical thinking and the background to teach it, but also must have the appropriate foundational beliefs. A teacher who regards knowledge as fixed and not subject to critique will not be disposed to teach critical thinking. Neither will the teacher who regards any claim about what is true or morally right as being a mere matter of taste have an appropriate worldview to teach critical thinking (Leming, 1998). Kurfiss (1988) posits that those who do not realize that knowledge is contextual may use critical thinking to bolster their own pre-conceived views (Paul's weak sense critical thinking) and may criticize a professor who teaches for critical thinking as not presenting them with the facts. As Court (1993) determined with her study of 120 Kindergarten to Grade 12 teachers, one needs to be open-minded in order to teach critical thinking.

McCarthy-Tucker (2000) studied the philosophical orientations of 104 preservice teachers in the Southwestern U.S.A. and of 10 of their instructors. She found that the pre-service teachers espoused the two philosophical orientations least likely to facilitate the development of critical thinking. These were a humanistic view (53\%) which is rooted in existential philosophy with the aim of education being self-actualization, and the executive/custodial view (27\%) stressing structure and order and utilizing a punitive approach. However, the pre-service teachers' instructors $(50 \%)$ favored a classical approach to education where disciplinary standards of critical thinking would be stressed. On the other hand, Vinson (1998) found in a national study of 500 high school social studies teachers in the U.S.A. that they were more likely to espouse instructional approaches conducive to critical thinking than those focussing on the acquisition of facts and the transmission of politically acceptable viewpoints. This finding reinforces that of Anderson et al. (1997). They found in their sample of 361 members of the National Council for the Social Studies that $47 \%$ of them supported a critical thinking approach to social studies. These teachers strongly agreed with statements that students should question the status quo and not obey unquestioningly all laws. However, what is 
not known is whether these beliefs were translated into practice. We do know that in a three year project involving intensive training of seven secondary teachers of United States history in three schools in the northeast of the U.S.A., the teachers did not implement critical thinking (McKee, 1988). According to the researcher's classroom observations, these teachers only taught for critical thinking in $4 \%$ of their classes. The teachers viewed knowledge as fixed and students as being incapable of critical thought because they did not know enough.

White (2000) interviewed 20 pre-service teachers in a mid-Western university about their solutions to a problematic classroom incident. She noted that 15 of these teachers reflected a relativistic view of knowledge, two were close to the absolutist position and only three could be described as critically reflective as measured by Perry's intellectual development instrument (Perry, 1970). Those identified as relativist made such comments as, "An expert isn't any better than a person without that knowledge," (p. 292) and, when deciding which alternative might be better, one teacher said, "You think what would be best . . [but] not saying which is better because you never can say what's better" (p. 291). In another study using Perry's schema, Pape and Keeley (1990) found that 77 preservice teachers did not appeal to evidence in resolving a teaching dilemma. Rather they appealed to idiosyncratic beliefs. Both these studies involved the resolution of a teaching problem. We do not know if the findings would generalize to other situations where critical thought is required.

From the evidence available, we cannot be certain whether teachers hold epistemological positions conducive to the teaching of critical thinking. Further, even if teachers were epistemologically disposed to teach critical thinking, other factors might mitigate against their actually teaching it.

There is some evidence that other qualities teachers bring to their teaching tasks are not in keeping with those required for the development of critical thinking. Nugent (1990) identifies one such prerequisite as the disposition to discuss values. This was not evidenced in Nelson, Pooler and Drake's (1994) study of 350 Middle and High School teachers in Maine and Illinois. These teachers did not engage their students in debate or inquiry during the Gulf War-a topic where values cannot fail to be raised. Even those teachers who were predisposed toward a reflective inquiry orientation (as measured by a Social Studies Preference Scale) did not use inquiry strategies, although they did devote more class time to the war than their less reflectively oriented colleagues. While there are findings that teachers avoid controversial issues (Cuban, 1984), there are also studies that indicate that $70 \%$ of American high school students discuss controversial issues in their social studies classes. What is disquieting about this figure is that only $50 \%$ of the students surveyed said they were free to express opinions that were contrary to those of their teachers (Hahn, 1991). Thus, we have teachers who do not raise controversial issues at all, those who permit discussion so long as the opinions expressed are in accord with those of the teachers, and those who at least discuss 
issues in an open environment. In the latter case, we have no evidence as to whether the discussions did anything to advance critical thought.

Clearly, generalizations about teacher beliefs can only be tentative. What is clear is that teacher beliefs influence their teaching. Yet, because the work of teachers is often ill-defined, educational beliefs become an "entangled" domain (Pajares, 1992, p. 311). This results in teachers being uncertain about what to do, leading them to take what is deemed the safest course of action-and teaching critical thinking is not a safe action!

\section{Teachers' moral reasoning}

If the teaching of critical thinking is to be implemented in schools, then teachers must be prepared to deal not only with empirical and conceptual questions, but also with ethical ones. In fact, if critical thinking is to have any bite, then it ought to be used to analyze and resolve moral issues, as they are frequently the ones that tend to be the most relevant and interesting to students (Wright and LaBar, 1991). Thus, how teachers reason about moral issues is of import. Further, if teachers are to teach for critical thinking, then they must exhibit certain moral characteristics, for example, treat students with respect, be willing to subject their beliefs to critical scrutiny, and encourage exploration of alternative points of view (Siegel, 1988).

When teachers are surveyed about their views on the importance of morality in schooling, results indicate that such virtues as respect and fairness are viewed as important (Joseph and Efron, 1991). However, only 50\% of Joseph and Efron's sample thought that students should challenge prevailing values. Zhixin Su (1990) found that there was very little moral discourse in teacher education programs and that, if Values Clarification strategies were used, teachers tended to view moral issues in a relativistic way, where anyone's opinion is as good as anyone else's.

One way to ascertain the moral reasoning of teachers is to use Kohlberg's theory of moral development. In this regard, it can be argued that teachers would have to be at Stage 3 or above to participate effectively in a critical thinking discussion, and that the principled Stage 5 would be better. Only at this stage can prevailing societal values be subject to critical scrutiny and universal, rather than parochial or societal, principles of justice be appealed to. While no studies of social studies teachers in particular could be located, the overall tendency for teachers is to be below Stage 5. For example, Lampe and Walsh (1992) report P. scores (scores which exhibit reasoning at stages 5 and 6 of Kohlberg's theory) on the Defining Issues Test (Rest, 1986) of 34.7 for junior and senior education students $(\mathrm{n}=90)$, and 35.5 for practicing teachers $(\mathrm{n}=94)$. These are lower than the average mean P. score for college students, as reported by Rest (1986), of 42.3 and 40.0 for adults. In the Lampe and Walsh study, only teacher educators (n. $=32$ ) had high scores ( $\mathrm{P} .=51.3)$. Only $23.4 \%$ of practicing teachers had $\mathrm{P}$. scores of $50 \%$ or above. MacCallum (1991) found that the mean of 39.5 for the teachers 
in his study was lower than that identified in other studies of high school students. It is unlikely that teachers could raise the level of critical moral discourse with their students if they display lower levels of reasoning than their students.

There is also evidence that teachers are confused about the nature of morality and what to do in the classroom when moral questions arise. Boyd (1980), in his exploratory study involving 20 teachers, found that they all had moral aims (e.g., teaching respect for others), that some were absolutists and some were relativists, but that many of them were confused about what to do in particular situations. As one respondent said, "It's the not knowingness [about what to do] that makes it difficult" (p. 14). If teachers do not know how to proceed when there is a critical moral challenge, then they will be unable to help students grapple with one either.

Sirotnik (1990) asked 128 pre-service teachers whether there were any consistent values, beliefs, or moral imperatives that drive what went on in their teacher education program. He reports that the question "drew an initial blank. Sometimes they were speechless" (p. 712). Lyons (1990) found that teachers in her sample thought that $70 \%$ of the conflicts they faced in their professional lives were ethical ones and they thought that the majority of these were unresolvable. If there is no way of resolving such issues, then there will be little inclination to raise them in the classroom. Bergem (1990) in his semi-structured interview study of 65 pre-service teachers found that those with high scores on a progressivism scale valued equal rights, respect for others, cooperation, and independent learning. Those who scored high on traditionalism indices were task-oriented, and focussed on teaching the 'basics' and ethics as dogma. Neither of these is conducive to the teaching of critical thinking.

These studies suggest the hypothesis that teachers are confused about the nature of morality and thus would have little or no theory on which to base the critical discussion of moral questions in their classrooms. Coupled with the evidence on teacher beliefs, my hypothesis is that, in the main, teachers do not possess the requisite dispositions, abilities or ethical beliefs to implement critical thinking in their classrooms.

\section{The school milieu}

Question: How do the milieus in which teachers work influence their decisions to teach critical thinking?

If there is doubt about the capabilities and dispositions of teachers to teach critical thinking, there is, 1 think, far more doubt about creating an educational climate which is conducive to critical thinking. There are hundreds of objectives in curriculum guides having to do with the development of reasoning and the dispositions needed to reason well, but there seems to be very little commitment to actually implementing them. Despite the fact that the business community appears to want graduates who can think well and solve problems, there are very few curriculum materials that go beyond the skills conception of critical thinking. For, 
when one goes beyond skills talk, then one is confronted with the real problems that confront the teaching of critical thinking-problems that raise fundamental epistemological and ethical questions. Here, I think, lies the 'danger' of critical thinking. Students might (in fact, ought to) challenge conventional wisdom and, especially, prevailing political views. And that is revolutionary. Even if after thinking critically about an accepted truth or policy the student comes to accept that truth or policy, the mere fact that the student is encouraged to do this is seen as dangerous. It is forgotten that critical thought can bolster known truths or presently accepted policies-that is, the student now has good reasons to believe or accept them.

This problem is interrelated with another. As has been seen previously, the prevailing wisdom seems to be that students need a great deal of information before they can think critically. As the knowledge "explosion" continues, it is assumed that students need ever-increasing amounts of information. In fact, in British Columbia the tendency is to create more prescriptive objectives and to mandate the use of Instructional Resource Packages in which the only good objectives are those that are measurable. Teaching critical thinking needs time, and the thrust to cover more and more material and always teach for measurable objectives runs counter to developing it.

In his classroom thoughtfulness project, Newmann (1992) lists six dimensions that are crucial if critical thinking is to occur. Two of these are that, "there is sustained coverage of a few topics rather than superficial coverage of many" and, "students are given an appropriate amount of time to think, that is to prepare responses to questions." That there is too much information to cover was a source of frustration to social studies teachers in British Columbia who wanted far more emphasis on problem-solving, decision-making and critical thinking (Bognar, Cassidy and Clarke, 1997). If the prevailing view is that information is divorced from critical thinking - facts are inert and have but to be memorized - then there is little hope that critical thinking will be more than a slogan.

Cornbleth (2001) suggests that there are five "climates" of constraints on meaningful learning in schools: law and order, conservatism, censorship, pathology and pessimism, and competitiveness.

The law and order climate relates to the focus on obedience to school rules as the prerequisite to, and major influence on learning. If the bureaucracy champions quiet and orderly learning, then it might well denounce critical thinking lessons, which two researchers report are often chaotic (Grant, 1988; Moore and Wright, 2000). Where administrators emphasize law and order, teachers choose to simplify content and reduce demands on students in order to reduce student resistance and get their compliance.

Conservatism is focused on maintaining the status quo. If the status quo is conducive to critical thought, then it is clearly worth maintaining. However, the 
status quo appears to be that teachers are socialized into the dominant, non-reflective modes of thought by colleagues, parents, students and prevailing community mores. These modes emphasize the acquisition of facts and the passing of exams. Innovations upset the "normal desired state" (Leat, 1999, p. 393)-the criterion appealed to by teachers to judge their lessons. As Leat found, thinking skills lessons in the United Kingdom upset the normal desired state of classrooms. The content was new to both teachers and students, students were sometimes confused, students found the lessons to be difficult, lessons often became chaotic, students did not respect opinions that differed from their own; and teachers could not resolve the perceived tension between teaching thinking skills and acquiring content knowledge.

Threats or actual cases of censorship can have a chilling effect on what is taught. If parents or other groups challenge the use of particular learning materials and books in classrooms or in the school library because they present unacceptable views, there is little inclination for teachers to present any controversial material in class in case they, too, get tarred with a radical brush.

"Pathology" and "pessimism" refer to the climate where students are perceived to have problems and thus cannot be expected to think critically. This tends to occur in low SES areas, but it can occur in any school where certain students, either individually or collectively, are viewed as problems. These students are often treated as if they are incapable of any critical thought. This pessimism is also found in one post-secondary institution that was studied by Tsui (2001). She quotes one faculty member at a college as remarking that it was impossible for $D$ level and C-level students to think critically (p. 10). However, Tsui also found in another institution that faculty did teach for critical thinking because they did not share the same pessimism and were prepared to work together to infuse critical thinking into their courses.

If the move for more accountability in schooling continues, more testing of students will likely occur and more focus will be placed on teaching students what is likely to appear on provincial/state or national tests (usually questions which demand low level factual knowledge). This impetus for testing continues to grow and, given the large number of students who will be tested, it is extremely unlikely that items testing for genuine critical thinking will be administered. As many scholars in the field of critical thinking have pointed out, the best ways of testing involve essay responses or analyzing people's deliberations in situations where critical thinking should occur (Norris and Ennis, 1989). Competition seems to be on the upsurge. Where results of testing are made public, sometimes in the form of league tables, then there is great motivation for teachers to teach to the test. This, of course, is likely to lead to more formal learning methods and less critical thinking.

These constraints on teaching for critical thinking are usually found in schools, not universities. However, post-secondary instructors who are interested in get- 
ting critical thinking infused in all courses should consider whether any of them are relevant to the post secondary context.

My hypothesis is that the constraints on the implementation of critical thinking in the schools outweigh any incentives.

\section{Conclusion}

Despite the rhetoric of critical thinking in social studies, the available evidence leads me to conclude that not much in the way of critical thinking does occur or is likely to occur in social studies classrooms in the near future. The evidence suggests that teachers hold a skills conception of critical thinking and are confused about the differing messages concerning how to teach critical thinking. I further hypothesize that teachers do not have the necessary abilities, dispositions and ethical beliefs that are conducive to critical thinking. Whether they have the necessary epistemology is unclear. Yet, even if teachers had the necessary abilities, knowledge and dispositions, the school milieu mitigates against the teaching of critical thinking. There is far too much emphasis on content coverage (rather than on deeper understanding of fewer topics), and standardized testing in the name of accountability. Censorship and a fear of teaching controversial issues also exist. The belief is widespead that either all students need to fully understand a topic before they can think critically about it, and/or that some students are incapable of critical thought.

If the folkways of teaching (the use of non-reflective, taken-for-granted patterns of teaching behavior) are not modified by teaching expertise (Buchmann, 1987), then the implementation of critical thinking will be little more than a fond hope. To modify the folkways will require means which "give ordinary teachers under ordinary circumstances, and with ordinary preparation, an objective chance to meet the demands of their work" (Buchmann, p. 159). This would appear to be a monumental task, given the demands made on teachers and the contexts in which they work. Yet, there are sites in which critical thinking is taken seriously, where teachers are committed to helping their students reason well. In my own province of British Columbia, in Canada, there is a cooperative venture involving school boards, provincial specialist associations of the British Columbia Teacher's Federation, and university faculty. Members are holding workshops and developing critical thinking materials (Daniels and Case, 1997). In the U.S.A., Richard Paul's Foundation for Critical Thinking continues to offer workshops and produces curriculum materials and assessment instruments. Further, one hears of other examples in journals, magazines, newsletters and newspapers where individual teachers are engaging students in activities that demand critical thought. There is some hope. Those of us who are committed to the teaching of critical thinking need not be completely pessimistic, but we face a critical challenge. ${ }^{2}$ 


\section{Notes}

The exception is where the Philosophy for Children program is taught in separate timetabled slots.

${ }^{2}$ Sincere thanks to Don Hatcher for his critique of a draft of this article

\section{References}

Anderson, R., Avery, P., Pederson, P., Smith, E., \& Sullivan, J. (1997). "Perspectives on citizenship education: A Q-method study and survey of social studies teachers." American Education Research Journal, 34, 333-364.

Bailin, S., Case, R., Coombs, J., \& Daniels, L. (1999a). "Common misconceptions of critical thinking." Journal of Curriculum Studies, 31(3), 269-283.

Bailin, S., Case, R., Coombs, J., \& Daniels, L. (1999b). "Conceptualizing critical thinking," Journal of Curriculum Studies, 31(3), 285-302.

Barr, R., Barth, J., \& Shermis, S. (1977). Defining the social studies. Arlington, Virginia: National Council for the Social Studies.

Bell, J. (2001) http://academic.pg.cc.md.us/ wpierce/MCCCTR/bell.html.

Bergem, T. (1990). "The teacher as moral agent." Journal of Moral Education, 19(2), 88-100.

Beyer, B. (1989). Teaching thinking skills: A handbook for elementary school teachers. Boston: Allyn and Bacon.

Beyer, B. (1991). Teaching thinking skills: A handbook for secondary school teachers. Boston: Allyn and Bacon.

Bognar, C., Cassidy, W., \& Clarke, P. (1997). British Columbia assessment of Social Studies 1996: Technical report. Victoria, BC: Ministry of Education Skills and Training.

Boyd, D. (1980). "Teachers reflections on morality: An exploratory study." Moral Education Forum, 5(4), 4-15.

Boyer, E. (1983). High school. New York: Harper and Row.

Buchman, M. (1997). "Knowledge: The lights that teachers live by." Oxford Review of Education, 13(2), 151-164.

Case, R., \& Wright, I.. (1997). Taking seriously the teaching of critical thinking. In R. Case \& P. Clark. (Eds.). The Canadian Anthology of Social Studies. Burnaby, BC: Field Relations and Teacher In-service Education, Simon Fraser University.

College Board. (1983). Academic preparation for college. New York: Entrance Examination Board.

Commission on the Humanities. (1980). The humanities in American life. Berkeley, California: University of California Press.

Cornbleth, C. (200I). "Climates of constraint/restraint of teachers and teaching." W. Stanley (Ed.), Critical issues in social studies research for the $21^{\text {st }}$ Century Greenwich, Conn: IAP. 


\section{Ian Wright}

Court, D. \& Francis, L. (1993). "Teachers' conceptions of critical thinking." McGill Journal of Education, 28(3), 479-487.

Cuban, L. (1984). How teachers teach. New York: Longman.

Daniels, L. \& Case. R. (1997). Critical challenges across the curriculum. Burnaby, British Columbia: Field Relations and Teacher-in-Service Education, Simon Fraser University.

Degenhardt, M. (1988). "Beware of skills talk: a cautionary note from a reader." Curriculum Perspectives, 8(2), 62-65.

Ennis, R. (1991). "Critical thinking: A streamlined conception." Teaching Philosophy, $14(1), 5-24$.

Fraenkel, J. (1991). Editorial. Theory and Research in Social Education, 19(4), 323-325.

Ford, C. (1988). "Macro-implementation of critical thinking in British Columbia's social studies curriculum." M.A. Thesis. Centre for the Study of Curriculum and Instruction, The University of British Columbia.

Goodlad, J., Soder, R., \& Sirotnik, K. (1990). The moral dimensions of teaching. San Francisco: Jossey-Bass.

Grant, G. (1988). Teaching critical thinking. New York: Praeger.

Hahn, C. (1991). "Controversial issues in social studies." In J. Shaver (Ed.), Handbook of research on social studies teaching and learning. Toronto: Collier Macmillan.

Hart, W. (1993). "Against skills." In M. Lipman (Ed.), Thinking, children and education. Duquque, Iowa: Kendall Hunt.

Hatcher, D. (2000). "Arguments for another definition of critical thinking." Inquiry: Critical thinking across the disciplines, 20(1), 3-8.

Janis, I., \& Mann, L. (1977). Decision making: A psychological analysis of conflict, choice and commitment. New York: The Free Press.

Johnson, R.H., \& Blair, J.A. (1994). "Informal logic: Past and Present." In R.H. Johnson and J.A. Blair (Eds.), New Essays in Informal Logic. Windsor, ON: Informal Logic.

Joseph, P. \& Efron, S. (1991). "Moral choices/moral conflicts: Self-perceptions of school teachers." Paper presented at the Annual Meeting of the American Educational Research Association, Chicago, ERIC ED 332376.

Kuhn, D. (1990). The skills of argument. New York: Cambridge University Press.

Kurfiss, J. (1988). Critical thinking: Theory, research, practice, and possibilities. Washington, D.C.: Association for the Study of Higher Education.

Lampe, J. \& Walsh, S. (1992). "Reflective teachers' ethical decision-making processes." Paper presented at the Annual Meeting of the American Educational Research Association, San Francisco, ERIC ED346048.

Leat, D. (1999). "Rolling the stone uphill: Teacher development and the implementation of Thinking Skills programmes." Oxford Review of Education, 25 (3), 388-403.

Leming, J. (1998). "Some critical thoughts about the teaching of critical thinking." The Social Studies, 89(2), 61-66.

Lipman, M. (1988). Critical thinking: What can it be? Institute for Critical Thinking Resource Publications, Series 1, No. 1. Upper Montclair: Montclair State College.

Lyons, N. (1990). "Dilemmas of knowing: Ethical and epistemological dimensions of teachers' work and development." Harvard Educational Review, 60(2), 159-180. 
MacCallum, J. (1991). "Teacher reasoning and moral judgment in the context of student discipline situations." Paper presented at the Annual Meeting of the American Educational Research Association, Chicago.

McCarthy-Tucker, S. (2000). "Teaching style, philosophical orientation and the transmission of critical thinking skills in U.S public schools." The Korean Journal of Thinking and Problem Solving, 10(1), 69-77.

McKee, S. (1988). "Impediments to implementing critical thinking." Social Education, 52(6), 444-446.

McPeck, J. (1998). Critical Thinking and Education. Toronto: Oxford University Press.

Moore, D., \& Wright, I. (2000) "Is that right?' The critical thinking of some grade 9 female students." Korean Journal of Thinking and Problem Solving, 10(2), 67-77.

National Council for the Social Studies. (1994). Curriculum standards for social studies. Washington, DC: National Council for the Social Studies.

Nelson, L., Pooler, A., \& Drake, F. (1994). "Treatment of the Gulf War by secondary social studies teachers." The Social Studies, 85(2), 76-82.

Newmann, F. (1991). "Higher order thinking in social studies." In J. Voss, D. Perkins, and J. Segal (Eds.). Informal Reasoning and Education. Hillsdale, NY: Erlbaum.

Newmann, F. (1992). "The prospects for classroom thoughtfulness in high school social studies." In C. Collins and J. Mangieri (Eds.),Teaching thinking: An agenda for the 21st century. NY: Hillsdale.

Norris, S. \& Ennis, R. (1989). Evaluating critical thinking. Pacific Grove.CA: Midwest Publications.

Nugent, S. (1990). "Five prerequisites for teaching critical thinking." Research and Teaching in Developmental Education, 6(2), 85-96.

Onosko, J. (1991). "Barriers to the promotion of higher-order thinking in social studies." Theory and Research in Social Education, 19(4), 341-366.

Pajares, M. (1992). "Teachers' beliefs and educational research: Cleaning up a messy construct." Research Review of Educational, 62(3), 307-332.

Pape, S., \& Keely, D. (1990). "Development of a written assessment device for determining reflective judgment. "Paper presented at the Midwest Educational Research Association Conference, October. ERIC ED 326537.

Parker, W. (1991). "Achieving thinking and decision-making objectives in social studies." In J. Shaver (Ed.), Handbook of Research on Social Studies Teaching and Learning. Toronto: Collier Macmillan.

Paul, R. (1982). "Teaching critical thinking in the strong sense: A focus on self deception, world views and dialectical mode of analysis." Informal Logic, 4 (2), 2-7.

Paul, R. (1992). "Why students-and teachers-don't reason well." In R. Paul, Critical thinking: What every person needs to know in a rapidly changing world. Rohnert Park, California: Center for Critical Thinking and Moral Critique, Sonoma State University.

Paul, R., Elder, L., \& Bartell, T. (1997). California teacher preparation for instruction in critical thinking: Research findings and policy recommendations. Sacramento, $\mathrm{CA}$ : California Commission on Teacher Credentialing. 
Perry, W. (1970). Forms of intellectual and ethical development in the college years. New York: Holt, Rhinehart and Winston.

Rest, J. (1986). DIT: Manual for the defining issues test. Minneapolis, Minnesota: University of Minnesota Center for the Study of Ethical Development.

Risby, B. (1987). Logic countdown. Logic liftoff. Orbiting with logic. San Luis Obispo, California: Dandy Lion Publications.

Siegel, H. (1988), Educating reason. New York: Routledge.

Sirotnik, K. (1990). "On the eroding foundations of teacher education." Phi Delta Kappen, 71 (9), 710-716.

Su, Zhixin. (1990). "Exploring the moral socialization of teacher candidates." Oxford Review of Education, 16 (3), 367-391.

Task Force on Education for Growth of the Education Commission of the States. (1983). Action for excellence. Denver, Colorado: Education Commission of the States.

Tsui, L. (2001). "Faculty attitudes and the development of students' critical thinking." Journal of General Education, 50(1), 1-28.

Unks, G. (1985). "Critical thinking in the social studies classroom: Do we teach it?" Social Education, 49 (3), 240, 244-246.

Vinson, K. (1998). "The 'traditions' revisited: Instructional approach and high school social studies teachers." Theory and Research in Social Education, 26(2), 50-82.

White, B. (2000). "Pre-service teachers' epistemology viewed through the perspectives on problematic classroom situation." Journal of Education for Teaching, 26(3), 279-305.

Wright, 1. (1993a). "Critical thinking: Curriculum and instructional policy implication." Journal of Educational Policy, 7(l), 37-43.

Wright, 1. (1993b). "Selected characteristics of pre-service teachers' practical reasoning." Unpublished paper. Department of Curriculum Studies, The University of British Columbia.

Wright, I. \& LaBar, C. (1991). Thinking critically about moral questions. Resource Publication Series 4, No. Upper Montclair: Montclair State College, Institute for Critical Thinking, State University, New Jersey.

lan Wright

Department of Curriculum Studies

University of British Columbia

2125 Main Mall

Vancouver, British Columbia

Canada, V6T 124.

ian.wright@ubc.ca 